\title{
Cross refractoriness between sodium metabisulphite and exercise induced asthma
}

\author{
I Pavord, H Lazarowicz, D Inchley, D Baldwin, A Knox, A Tattersfield
}

\begin{abstract}
Background - Exercise and inhaled sodium metabisulphite are thought to cause bronchoconstriction in asthma through different mechanisms. The response to both stimuli becomes refractory with repeat challenge. The mechanism of refractoriness is unclear, although depletion of mast cell derived mediators or neurotransmitters has been suggested. Recent studies suggest a common mechanism involving release of inhibitory prostaglandins. If this is true, exercise and sodium metabisulphite induced bronchoconstriction should show cross refractoriness.
\end{abstract}

Methods - Thirteen subjects with mild asthma and previously established exercise and sodium metabisulphite induced bronchoconstriction performed two sodium metabisulphite challenges (giving a single dose previously shown to cause a $20 \%$ fall in $\mathrm{FEV}_{1}$ ) on one study day, and two exercise tests on another. The second challenge proceeded after recovery $\left(F E V_{1}>95 \%\right.$ baseline) from the first. Subjects then attended on two further occasions when an exercise test was performed after sodium metabisulphite and a sodium metabisulphite challenge after exercise.

Results - When expressed as the percentage reduction in the area under the change in percentage FEV $_{1}$ curve over 20 minutes (AUC) the response to exercise $46.5 \%$ to $78 \cdot 1 \%$ ) following a first exercise challenge, and by $50.7 \%(95 \%$ CI $27 \cdot 8 \%$ to $73.6 \%$ ) following a sodium metabisulphite challenge. The response to a sodium metabisulphite challenge was reduced by a mean of $80.2 \%(95 \%$ CI $68.9 \%$ to $91.5 \%)$ when it followed a sodium metabisulphite challenge, and by $37 \cdot 3 \%$ (95\% CI $15 \cdot 1 \%$ to $59 \cdot 5 \%$ ) following an exercise challenge.

Respiratory Medicine Unit, City Hospital, Nottingham NG5 1PB, UK

I Pavord

H Lazarowicz

D Inchley

D Baldwin

A Knox

A Tattersfield

Reprint requests to: Dr I Pavord.

Received 20 April 1993 Returned to authors 12 November 1993 Revised version received 18 November 1993 Accepted for publication 22 November 1993

\section{(Thorax 1994;49:245-249)}

The response to a number of bronchoconstrictor challenges in asthma shows refractoriness that is, a tendency to diminish with repeat challenge. This occurs most clearly after chalwas reduced by a mean $62.3 \%(95 \% \mathrm{CI}$

lenges which cause bronchoconstriction through indirect mechanisms such as exercise, ${ }^{1}$ ultrasonically nebulised distilled water, ${ }^{2}$ adenosine 5 '-monophosphate, ${ }^{3}$ and sodium metabisulphite, ${ }^{4}$ and is unusual with directly acting challenges such as histamine. ${ }^{56}$ The mechanism is unclear, although it has been suggested that refractoriness to exercise, ${ }^{1}$ ultrasonically nebulised distilled water, ${ }^{2}$ and adenosine $5^{\prime}$ monophosphate induced bronchoconstriction ${ }^{3}$ is due to depletion of mast cell derived mediators. Such a mechanism would not, however, explain refractoriness to sodium metabisulphite where bronchoconstriction is thought to involve neural reflexes and not mast cell mediator release. ${ }^{78}$

The cyclooxygenase inhibitor indomethacin inhibits the development of refractoriness to exercise, ${ }^{9}$ ultrasonically nebulised distilled water, ${ }^{10}$ and sodium metabisulphite, ${ }^{4}$ raising the possibility of a common mechanism of refractoriness involving the formation of inhibitory prostaglandins. We have tested the hypothesis that refractoriness to sodium metabisulphite and exercise induced asthma involves a common mechanism by seeking evidence of cross refractoriness. We measured the response to a single dose of sodium metabisulphite so that the response to exercise and sodium metabisulphite could be analysed in the same way.

\section{Methods}

SUBJECTS

Thirteen men aged 18 to 46 years with mild asthma requiring inhalation treatment only were recruited from the City Hospital asthma register. Four subjects were taking an inhaled corticosteroid regularly (beclomethasone 200$800 \mu \mathrm{g}$ daily), one was taking inhaled sodium cromoglycate, and all took an inhaled $\beta_{2}$ agonist as required. Beta ${ }_{2}$ agonists were withheld for six hours and sodium cromoglycate for 12 hours before each visit. Subjects were nonsmokers, had a forced expiratory volume in one second $\left(\mathrm{FEV}_{1}\right)$ of greater than $60 \%$ predicted, and showed a fall in $\mathrm{FEV}_{1}$ after a preliminary exercise test of more than $15 \%$. After verbal and written explanation of the study subjects gave signed consent to participate; the protocol was approved by the City Hospital ethics committee.

\section{MEASUREMENTS}

$\mathrm{FEV}_{1}$ was measured on a dry bellows spirometer (Vitalograph, Buckingham, UK) as the 
higher of two successive readings within $100 \mathrm{ml}$. The provocative dose of sodium metabisulphite required to cause a $20 \%$ fall in $\mathrm{FEV}_{1}$ $\left(\mathrm{PD}_{20}\right)$ was established using a MEFAR (Bresca, Italy) breath activated dosimeter to give doubling doses up to a maximum of $128 \mu \mathrm{mol}$ as described. ${ }^{8}$ Exercise tests were performed at room temperature on an electric treadmill (Case 12, Marquette Electronics Inc, Milwaukee, USA). Subjects exercised for seven minutes whilst breathing dry air at room temperature through a mouthpiece connected to a Collins triple J valve, Douglas bag reservoir, and air cylinder. The speed and gradient of the treadmill were set at a level sufficient to maintain a heart rate of $80 \%$ of the predicted maximum for each subject. These settings were kept constant for all subsequent exercise tests.

\section{PROTOCOL}

Subjects attended on six occasions at the same time of day with visits separated by at least 48 hours. On the first two occasions they attended for a practice exercise test followed, on a separate day, by a sodium metabisulphite challenge to determine the sodium metabisulphite $\mathrm{PD}_{20}$. On the next occasion they attended for a single dose challenge with approximately the $\mathrm{PD}_{20}$ dose of sodium metabisulphite. $\mathrm{FEV}_{1}$ was measured before (baseline) and at intervals after the challenge. Subjects were rechallenged with the same dose of sodium metabisulphite after recovery $\left(\mathrm{FEV}_{1}>95 \%\right.$ baseline value) and $\mathrm{FEV}_{1}$ was then measured at intervals for 20 minutes.

Subjects reattended for two exercise challenges with the second challenge starting after recovery from the first $\left(\mathrm{FEV}_{1}>95 \%\right.$ baseline $)$. $\mathrm{FEV}_{1}$ was measured before the exercise test (baseline) and at intervals after the first challenge and at the same times for 20 minutes after the second challenge. On the final two study days subjects attended for a sodium metabisulphite challenge followed by an exercise challenge, and an exercise challenge followed by a sodium metabisulphite challenge. The order of challenges was randomised.

\section{ANALYSIS}

Sodium metabisulphite $\mathrm{PD}_{20}$ was calculated by linear interpolation of the log dose-response curve. The airway response to exercise and the single dose challenge with sodium metabisulphite was expressed as the percentage change from the $F E V_{1}$ recorded immediately before the challenge (baseline) and described as the maximum percentage fall in $\mathrm{FEV}_{1}$ and area under the change in $F E V_{1}$ percentage curve over 20 minutes (AUC). Baseline $\mathrm{FEV}_{1}$, the maximum fall in $\mathrm{FEV}_{1}$, and AUC for the first and second challenge were compared within subjects by a paired $t$ test and differences calculated with $95 \%$ confidence intervals $(\mathrm{CI})$ A refractory index was derived by expressing the difference between the AUC for the first and second challenge as a percentage of the first challenge AUC. In the second part of the study the response to sodium metabisulphite and exercise given as a first challenge (before exercise or sodium metabisulphite) was compared with the response to sodium metabisulphite and exercise when given as a second challenge (after exercise or sodium metabisulphite); a cross refractory index was derived by expressing the difference between the AUC for the first and second challenge as a percentage of the first AUC.

\section{Results}

Baseline $\mathrm{FEV}_{1}$ values before the first sodium metabisulphite and exercise challenges did not differ significantly. Baseline $\mathrm{FEV}_{1}$ values for the second sodium metabisulphite and exercise challenge were about $4 \%$ lower than the first, but did not differ significantly from each other. The median time to recovery was 50 minutes following a first exercise test, and 40 minutes following a first sodium metabisulphite challenge.

The maximum percentage fall in $\mathrm{FEV}_{1}$ after exercise was similar on the two occasions it was given as the first challenge $(25.8 \%$ before exercise and $22 \cdot 7 \%$ before sodium metabisulphite; table). When given as the second challenge the response to exercise was significantly reduced whether following an exercise test or sodium

Maximum percentage fall in FEV, after sodium metabisulphite and exercise challenge before and after sodium metabisulphite and exercise challenge with mean and $S E$ value

\begin{tabular}{|c|c|c|c|c|c|c|c|c|}
\hline \multirow{3}{*}{$\begin{array}{l}\text { Subject } \\
\text { no. }\end{array}$} & \multicolumn{4}{|l|}{ Sodium metabisulphite } & \multicolumn{4}{|l|}{ Exercise } \\
\hline & \multicolumn{2}{|l|}{ Before } & \multicolumn{2}{|l|}{ After } & \multicolumn{2}{|l|}{ Before } & \multicolumn{2}{|l|}{ After } \\
\hline & Sodium metabisulphite & Exercise & Sodium metabisulphite & Exercise & Exercise & Sodium metabisulphite & Exercise & Sodium metabisulphite \\
\hline $\begin{array}{r}1 \\
2 \\
3 \\
4 \\
5 \\
6 \\
7 \\
8 \\
9 \\
10 \\
11 \\
12 \\
13\end{array}$ & $\begin{array}{r}32.6 \\
30.7 \\
18.8 \\
30.7 \\
9.3 \\
19.7 \\
30.1 \\
20.8 \\
33.9 \\
23.3 \\
41.9 \\
32.3 \\
23.4\end{array}$ & $\begin{array}{l}33.5 \\
18.0 \\
17.8 \\
25.4 \\
13.8 \\
19.3 \\
52.8 \\
17.6 \\
51.3 \\
23.2 \\
39.6 \\
28.9 \\
32.4\end{array}$ & $\begin{array}{r}14.0 \\
10.4 \\
5.7 \\
15.9 \\
6.4 \\
2.2 \\
8.8 \\
4.8 \\
16.5 \\
13.1 \\
9.2 \\
8.8 \\
15.4\end{array}$ & $\begin{array}{r}14.6 \\
14.6 \\
13.6 \\
26.1 \\
11.1 \\
17.8 \\
10.5 \\
1.8 \\
46.7 \\
15.5 \\
27.9 \\
14.1 \\
39.6\end{array}$ & $\begin{array}{l}19.6 \\
40.0 \\
15.4 \\
32.8 \\
37.5 \\
16.1 \\
16.7 \\
21.4 \\
34.4 \\
20.0 \\
19.1 \\
28.5 \\
34.3\end{array}$ & $\begin{array}{l}15.4 \\
27.5 \\
17.5 \\
15.6 \\
28.1 \\
14.9 \\
25.7 \\
11.4 \\
29.5 \\
23.1 \\
15.1 \\
29.3 \\
42.2\end{array}$ & $\begin{array}{r}9.1 \\
26.3 \\
7.3 \\
2.6 \\
24.7 \\
8.8 \\
6.5 \\
3.4 \\
19.0 \\
12.4 \\
2.8 \\
25.2 \\
29.1\end{array}$ & $\begin{array}{r}11.9 \\
6.9 \\
9.2 \\
17.9 \\
26.3 \\
4.2 \\
14.4 \\
6.4 \\
10.1 \\
14.8 \\
0.5 \\
24.1 \\
39.1\end{array}$ \\
\hline $\begin{array}{l}\text { Mean } \\
\text { SE }\end{array}$ & $\begin{array}{r}26 \cdot 7 \\
2 \cdot 4\end{array}$ & $\begin{array}{r}28.8 \\
3.5\end{array}$ & $\begin{array}{r}10 \cdot 1 \\
1.3\end{array}$ & $\begin{array}{r}19.5 \\
3.5\end{array}$ & $\begin{array}{r}25 \cdot 8 \\
3.5\end{array}$ & $\begin{array}{r}22 \cdot 7 \\
2 \cdot 4\end{array}$ & $\begin{array}{r}13 \cdot 6 \\
2 \cdot 7\end{array}$ & $\begin{array}{r}14.3 \\
2 \cdot 9\end{array}$ \\
\hline
\end{tabular}




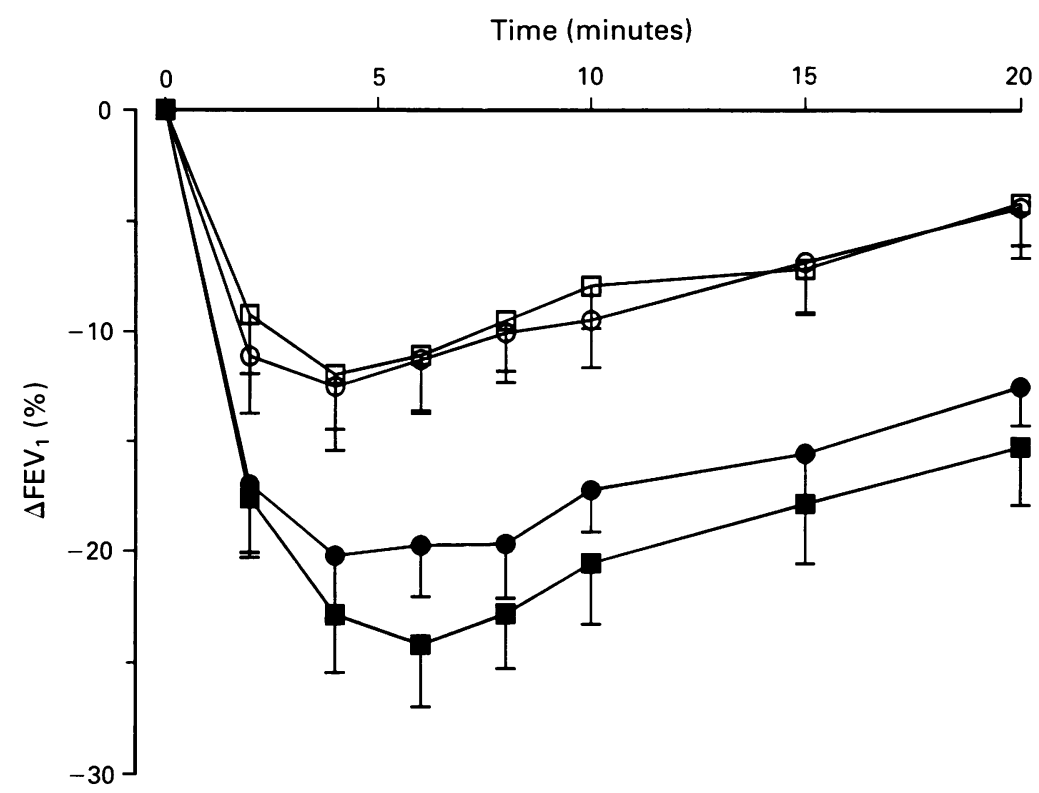

Figure 1 Percentage change in FEV against time after exercise. Points represent mean with standard error of mean. Closed squares = before exercise; closed circles = before sodium metabisulphite; open squares = after exercise; open circles $=$ after sodium metabisulphite.

metabisulphite (table, fig. 1). The mean maximum fall in $\mathrm{FEV}_{1}$ was $13.6 \%$ after exercise (mean difference from first exercise challenge $12.2 \% ; 95 \%$ CI $8 \%$ to $16.4 \% ; \mathrm{p}<0.001)$, and $14.3 \%$ after sodium metabisulphite (mean difference from response to exercise before sodium metabisulphite $8.4 \% ; 95 \%$ CI $4.3 \%$ to $12.5 \% ; \mathrm{p}<0.001)$.

The response to sodium metabisulphite was also similar on the two occasions it was given as the first challenge $(26.7 \%$ before sodium metabisulphite and $28 \cdot 8 \%$ before exercise; table). When given as the second challenge sodium metabisulphite caused a significantly smaller fall in $\mathrm{FEV}_{1}$ whether following sodium metabisulphite $(10 \cdot 1 \%$; mean difference $16.6 \% ; 95 \%$

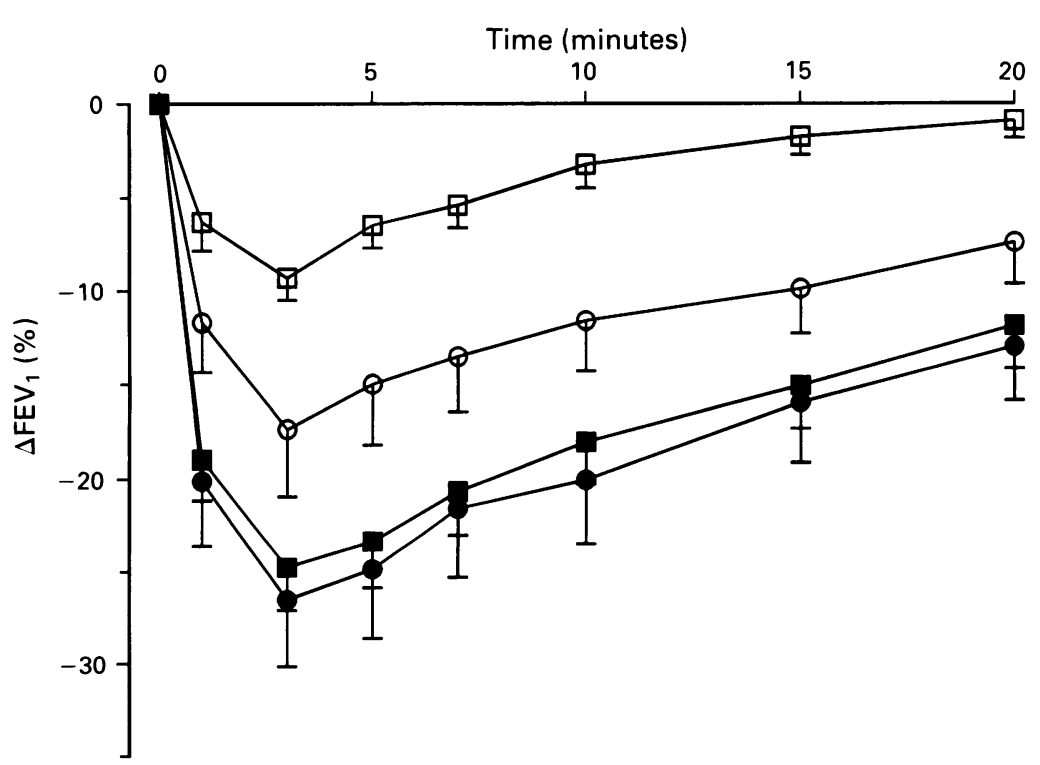
Figure 2 Percentage change in FEV, against time after sodium metabisulphite
challenge. Points represent mean with standard error of mean. Closed squares = before sodium metabisulphite; closed circles = before exercise; open squares = after sodium metabisulphite; open circles $=$ after exercise.
CI $12 \cdot 1 \%$ to $21 \cdot 1 \%$; $<0.001$ ) or exercise (19.5\%; mean difference $9.2 \% ; 95 \%$ CI $1.8 \%$ to $16.7 \%$; $<0.02$; table, fig 2 ).

When expressed as a percentage reduction in the AUC over 20 minutes the response to exercise was reduced by a mean $62.3 \%(95 \%$ CI $46.5 \%$ to $78.1 \%$; $\mathrm{p}<0.001)$ by a prior exercise test and by $50 \cdot 7 \%(95 \%$ CI $27 \cdot 8 \%$ to $73.6 \% ; \mathrm{p}<0.001)$ after a sodium metabisulphite challenge (figs 1 and 2). The response to a second sodium metabisulphite challenge was reduced by a mean $80.2 \%$ (95\% CI $68.9 \%$ to $91.5 \% ; \mathrm{p}<0.001)$ after a first sodium metabisulphite challenge and $37 \cdot 3 \%$ (95\% CI $15 \cdot 1 \%$ to $59.5 \% ; \mathrm{p}<0.01$ ) after exercise (figs 1 and 2 ).

\section{Discussion}

We have shown that considerable refractoriness develops after both exercise and sodium metabisulphite induced bronchoconstriction in subjects with mild asthma, in keeping with previous studies. ${ }^{14}$ The new finding and main point of interest of the present study is the demonstration of cross refractoriness between exercise and sodium metabisulphite induced bronchoconstriction.

Cross refractoriness has been shown between exercise induced bronchoconstriction and bronchoconstriction induced by hypertonic saline, ${ }^{11}$ and adenosine 5 '-monophosphate challenge has been shown to reduce the response to exercise ${ }^{12}$ and the early response to allergen in subjects with asthma, ${ }^{13}$ although it enhanced the response to allergen in atopic subjects. ${ }^{14}$ Cross refractoriness between different bronchoconstrictor challenges implies involvement of a common bronchoconstrictor pathway which becomes depleted, or activation of a common protective mechanism. The bronchoconstrictor response to exercise, ${ }^{15}$ adenosine $5^{\prime}$-monophosphate, ${ }^{16}$ and allergen ${ }^{16}$ is partially inhibited by antihistamine treatment, suggesting involvement of mast cell mediator release. Cross refractoriness could therefore be due to depletion of mast cell derived mediators. This would not, however, explain our finding of cross refractoriness between sodium metabisulphite and exercise induced asthma since, unlike exercise, sodium metabisulphite induced bronchoconstriction is not inhibited by antihistamines ${ }^{7}$ and is thought to be neurally mediated. ${ }^{48}$

Cross refractoriness between sodium metabisulphite and exercise induced bronchoconstriction could be due to depletion of another pathway, common to the mechanism of bronchoconstriction of both challenges. Loss of airway smooth muscle responsiveness after the first challenge seems unlikely since the response to the directly acting spasmogen histamine is unchanged after exercise challenge in subjects refractory to exercise induced bronchoconstriction. ${ }^{17}$ Whether depletion of cholinergic pathways could explain cross refractoriness between sodium metabisulphite and exercise induced bronchoconstriction is also open to doubt since antimuscarinic agents have minimal effect on exercise induced asthma. ${ }^{18}$ If non-adrenergic non-cholinergic 
excitatory neural pathways are involved in the bronchoconstrictor response to both exercise and sodium metabisulphite, cross refractoriness could result from depletion of neuropeptides, as has been shown in animal studies in vitro following repeated neural stimulation. ${ }^{19}$

The alternative explanation for cross refractoriness between exercise and sodium metabisulphite induced bronchoconstriction is activation of a common protective mechanism such as the release of catecholamines or inhibitory prostaglandins. Catecholamine release during a first challenge is perhaps less likely since this would be expected to have a similar effect on a second challenge irrespective of the mechanism of bronchoconstriction, and previous studies have shown that the response to histamine is unaffected by prior exercise challenge. ${ }^{17}$ Furthermore, refractoriness to exercise develops without a rise in the concentration of circulating catecholamines. ${ }^{20}$

A role for inhibitory prostaglandins in the aetiology of refractoriness is supported by studies showing attenuation by indomethacin of refractoriness after exercise, ${ }^{9}$ sodium metabisulphite, ${ }^{4}$ and osmolar challenges ${ }^{1021}$ in man, and allergen challenge in sensitised guinea pigs. ${ }^{22}$ The most likely candidate is $\mathrm{PGE}_{2}$ since this is a major cyclooxygenase metabolite of human airway epithelium ${ }^{23}$ and smooth muscle, ${ }^{24}$ and studies on canine and human airway smooth muscle in vitro show inhibition of cholinergic and non-cholinergic neurally induced contractions by low concentrations of $\mathrm{PGE}_{2}{ }^{2526}$ and inhibtion of mediator release from immunologically activated human lung mast cells by higher concentrations. ${ }^{27} \mathrm{PGE}_{2}$ has little or no direct relaxant or anticonstrictor effect on human airway smooth muscle in vitro ${ }^{24}$ so it would be expected to inhibit the response to bronchoconstrictor challenges acting through mast cell mediator release or neural pathways to a greater extent than those acting directly on airway smooth muscle. This view is supported by studies with inhaled $\mathrm{PGE}_{2}$ in asthma showing very effective protection against allergen, ${ }^{28}$ exercise, ${ }^{29}$ and sodium metabisulphite induced bronchoconstriction, ${ }^{30}$ but minimal effect on the response to the direct airway smooth muscle agonist methacholine. ${ }^{30}$

We did not show complete cross refractoriness between exercise and sodium metabisulphite induced bronchoconstriction, suggesting that other challenge specific mechanisms may contribute to refractoriness. There was, however, considerable cross refractoriness consistent with an important common component of refractoriness which may well involve inhibitory prostaglandins. The protective effects of frusemide in asthma (which preferentially inhibits the response to indirectly acting challenges ${ }^{31}$ ) can be attenuated by treatment with cyclooxygenase inhibitors, ${ }^{32-34}$ suggesting that there are similarities between the mechanism of action of frusemide and the mechanism of refractoriness. Inhibitory prostanoids, and $\mathrm{PGE}_{2}$ in particular, may therefore have a wider role as an endogenous protective factor against induced bronchoconstriction.
IDP is supported by a grant from the Medical Research Council. We thank Ms J Williams for help with subject recruitment, and Dr E Smyth and Mr A Wisniewski for help with the study.

1 McNeill RS Nairn JR, Millar JS, Ingram CG. Exerciseinduced asthma. $Q \mathcal{F}$ Med 1966;35:55-67.

2 Mattoli S, Foresi A, Corbo GM, Valente S, Culla G, Ciappi G. Refractory period to ultrasonic mist of distilled water: relationship to methacholine responsiveness, atopic status, and clinical characteristics. Ann Allergy 1987;58:134 40.

3 Daxun Z, Rafferty P, Richards R, Summerell S, Holgate ST. Airway refractoriness to adenosine 5 '-monophosphate after repeated inhalation. $\mathcal{f}$ Allergy Clin Immunol 1989;83:152-8.

4 Pavord I, Wisniewski A, Tattersfield A. Refractoriness to inhaled sodium metabisulphite in subjects with mild asthma. Eur Respir $\mathcal{F}$ (in press).

5 Ruffin RE, Alpers JH, Crockett AJ, AAIST, Hamilton R. Repeated histamine inhalation tests in asthmatic subjects. f Allergy Clin Immunol 1981;67:285-9.

6 Polosa R, Finnerty JP, Holgate ST. Tachyphylaxis to inhaled histamine in asthma: its significance and relationship to basal airway responsiveness. F Allergy Clin Immunol 1990;86:265-71.

7 Dixon CMS, Ind PW. Metabisulfite induced bronchoconstriction: mechanisms. Am Rev Respir Dis 1988;137:238.

8 Nichol GM, Nix A, Chung KF, Barnes PJ. Characterisation of bronchoconstrictor responses to sodium metabisulphite aerosol in atopic subjects with and without asthma. Thorax 1989;44:1009-14.

9 O'Byrne PM, Jones GL. The effect of indomethacin on exercise-induced bronchoconstriction and refractoriness after exercise. Am Rev Respir Dis 1986;134:69-72.

10 Mattoli S, Foresi A, Corbo GM, Valente S, Ciappi G. The effect of indomethacin on the refractory period occurring after the inhalation of ultrasonically nebulized distilled water. I Allergy Clin Immunol 1987;79:678-83.

11 Belcher NG, Rees PJ, Clark TJH, Lee TH. A comparison of the refractory periods induced by hypertonic airway challenge and exercise in bronchial asthma. Am Rev Respir Dis 1987;135:822-5.

12 Finnerty JP, Polosa R, Holgate ST. Repeated exposure of asthmatic airways to inhaled adenosine $5^{\prime}$-monophosphate attenuates bronchoconstriction provoked by exercise. f Allergy Clin Immunol 1990;86:353-9.

13 Holgate ST. Inflammatory cells and their mediators in the pathogenesis of asthma. Postgrad Med 7 1988;64(Suppl 4):82-95.

14 Phillips GD, Bagga PK, Djukanovic R, Holgate ST. The influence of refractoriness to adenosine $5^{\prime}$-monophosphate on allergen-provoked bronchoconstriction in asthma. Am Rev Respir Dis 1989;140:321-6.

15 Finnerty JP, Holgate ST. Evidence for the roles of histamine and prostaglandins as mediators in exercise-induced asthma: the inhibitory effect of terfenadine and flurbiprofen alone and in combination. Eur Respir ₹ 1990;3:540-7.

16 Rafferty P, Beasley R, Holgate ST. The contribution of histamine to immediate bronchoconstriction induced by inhaled allergen and adenosine 5 '-monophosphate in atopic asthma. Am Rev Respir Dis 1987;136:369-73.

17 Hahn AG, Nogrady SG, Tumilty McA, Lawrence SR, Morton AR. Histamine reactivity during the refractory period after exercise-induced asthma. Thorax 1984; 39:919-23.

18 Anderson SD. Exercise-induced asthma. The state of the art. Chest 1985;87(Suppl):191 S-5S

19 Brokaw JJ, Hillenbrand CM, White G, McDonald DM Mechanism of tolerance associated with neurogenic plasma extravasation in the rat trachea. Am Rev Respir Dis 1990;141:1434-40.

20 Belcher NG, Murdoch R, Dalton N, Clark TJH, Rees PJ, Lee TH. Circulating concentrations of histamine, neutrophil chemotactic activity, and circulating catecholamines during the refractory period in exercise-induced asthma. during the refractory period in exercise-

21 O'Hickey SP, Hawksworth RJ, Rees PJ, Lee TH. Effect of indomethacin on the refractory period to hypertonic saline-induced bronchoconstriction. Am Rev Respir Dis 1990;141:A655.

22 Dorsch W, Frey L. Allergen tachyphylaxis of guinea pigs in vivo: a prostaglandin $\mathrm{E}$ mediated phenomenon? NaunynSchmiedeberg's Arch Pharmacol 1981;317:351-6.

23 Churchill L, Chilton FH, Resau JH, Bascom R, Hubbard WC, Proud D. Cyclooxygenase metabolism of endogenous arachidonic acid by cultured human tracheal epithelial cells. Am Rev Respir Dis 1989;140:449-59.

24 Haye-Legrand I, Cerrina J, Raffestin B, Labat C, Boullet C, Bayol A, et al. Histamine contractions of isolated huma airway smooth muscle preparations: role of prostaglandins. F Pharmacol Exp Ther 1986;239:536-41.

25 Ito $\mathrm{Y}$, Tajima $\mathrm{K}$. Actions of indomethacin and prostaglandins on neuroeffector transmission in the dog trachea. f Physiol (Lond) 1981;319:379-92.

26 Ito I, Suzuki H, Aizawa H, Hirose T, Hakoda H. Prejunctional inhibitory action of prostaglandin $\mathrm{E}_{2}$ on excitatory neuro-effector transmission in the human bronchus. Prostaglandins 1990;39:639-55. 
27 Peters SP, Schulman ES, Schleimer RP, MacGlashan DW, Newball HH, Lichtenstein LM. Dispersed human lung mast cells. Pharmacologic aspects and comparison with human lung fragments. Am Rev Respir Dis 1982; 126:1034-9.

28 Pasargiklian M, Bianco S, Allegra L. Clinical, functional and pathogenetic aspects of bronchial reactivity to prostaglandins $\mathrm{F}_{2 x^{\prime}} \mathrm{E}_{1}$ and $\mathrm{E}_{2}$. Adv Prostaglandin Thromboxane Res 1976;1:461-75.

29 Pasargiklian M, Bianco S, Allegra L, Moavero NE, Petrigni $\mathrm{G}$, Robuschi $M$, et al. Aspects of bronchial reactivity to prostaglandins and aspirin in asthmatic patients. Respiration 1977;34:79-91.

30 Pavord I, Wisniewski A, Mathur R, Wahedna I, Knox A, Tattersfield A. Effects of inhaled prostaglandin $E_{2}$ on bronchial reactivity to sodium metabisulphite and methacholine in subjects with asthma. Thorax 1991;46:633-7. 31 Inhaled frusemide and asthma (editorial). Lancet 1990;335:944-6.

32 Pavord I, Wisniewski A, Tattersfield A. Inhaled frusemide and exercise-induced asthma. Evidence of a role for inhibitory prostaglandins. Thorax 1992;47:797-800

33 Polosa R, Rajakulasingham K, Prosperini G, Holgate ST. Cyclooxygenase inhibition modulates the change in bronchial reactivity to methacholine with inhaled frusemide in normal subjects (abstract). Thorax 1992;47:853.

34 Pavord I, Holland E, Baldwin D, Tattersfield A, Knox A. Frusemide and allergen-induced contractions of passively sensitised human bronchus: evidence of a role for prostaglandin $\mathrm{E}_{2}$ (abstract). Thorax 1992;47:895.

\section{Adventitia}

\section{Breathless on Everest - I}

"The problem with Everest is that it is just too damned high." This is not an original or surprising statement, but is one I made to myself several times as I struggled up the Lhotse face, desperately breathless and wishing that the mountain was just 10000 feet lower. Everest is, of course, very high. At 29028 feet it is approaching the edge of the earth's atmosphere and its summit often lies in the jet stream. Fiercesome winds of 120 miles an hour or more, which can easily sweep men and all their belongings off the mountain, are commonplace. Because of its height the air is, of course, also very thin. The atmospheric pressure is $253 \mathrm{~mm} \mathrm{Hg}$, one third the level at sea level, and that is the level of hypoxia with which climbers have to contend.

The mountain was first climbed in 1953, largely as a result of the work of Dr Griffith Pugh, physiologist with the MRC. He had accompanied an expedition to the base of the mountain in 1951 and made calculations of likely water loss, heat loss, and need for oxygen supplementation. Pugh's rules still hold. Most climbers use $2 \mathrm{l} / \mathrm{min}$ oxygen between Camp 3 at 23500 feet and Camp 4 at 26000 feet and then 3-4 litres of oxygen to get to the summit. No one had ever really tested Pugh's rules, so when I was asked to join the British 40th Anniversary Everest Expedition and given the rather grandiose title of High Altitude Physiologist, I thought that I would try, using modern miniaturised equipment, to see how hypoxic people get at these altitudes and to determine the effect of added oxygen.

The British 40th Anniversary Expedition to Everest had three main aims. The first was to commemorate Hunt's expedition and to follow the same route that Hillary and Tenzing had used in their triumphant ascent. The second was to raise money for the Himalayan Trust which was set up by Sir Edmund Hillary to provide schools and hospitals in the Khumbu region of Nepal but had recently become con- cerned with conservation in that increasingly desolate mountain region. The third was to put the first British woman on the summit of the mountain. As everyone now knows Rebecca Stephens made the summit in grand style, alone save for two Sherpas, and has got her name into the record books.

At the time I was invited to join the expedition I had very little climbing experience so I took myself on a crash training course which meant inveigling climbing friends into carting me up and down mountains. By the time I left for Everest I had terrified myself on rock crags and snow gullies all over Scotland and sheer limestone rock faces in Tuscany. I was not prepared, however, for the conditions I would experience on Everest.

We set off on 16 March 1993 from Kathmandu taking a bus to Jiri, a distance of 80 miles. The rest of the trip, approximately 150 miles, we had to walk. We arrived at Everest base camp, which is at 17500 feet, on 7 April 1993 and sat there looking up at the majestic Khumbu icefall above us. The icefall has claimed more lives on Everest than any other part of the mountain. I set up my tent looking directly up the icefall, just to remind myself every day how frightening it can be. The icefall consists of huge blocks of ice moving at about three feet a day. They are very unstable and constantly falling. Each one may be as big as a cathedral. Between them there are crevasses 100 feet deep. We climbed the blocks of ice on jumars and crampons and crossed the crevasses on roped aluminium ladders. I crossed it six times and that was undoubtedly six times too many. To cross it we would leave at about $2.00 \mathrm{am}$ and the great blocks of ice would be illuminated by the several head torches of the small party winding their way up this unstable environment.

ANDREW J PEACOCK

[Part II of Breathless on Everest appears on page 269] 